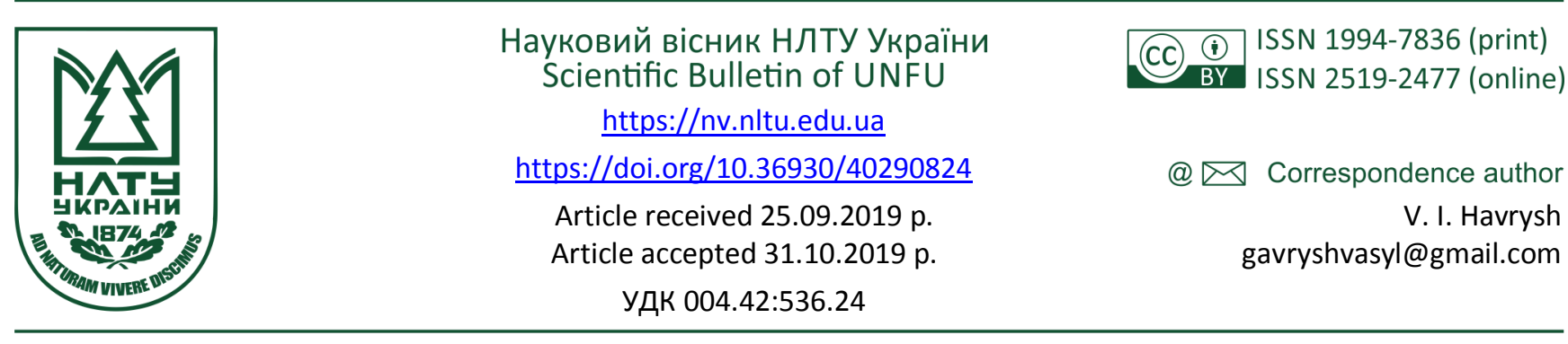

V. I. Havrysh, O. S. Korol, R. R. Shkrab, B. O. Kviatkovskyi

Lviv Polytechnic National University, Lviv, Ukraine

\title{
THERMAL 3D MODEL FOR NON-HOMOGENEOUS ELEMENTS IN MOBILE DEVICES
}

A mathematical model for the analysis of heat exchange between the environment and an isotropic space layer with an alien inclusions is developed, which is heated by a heat flux centered on one of the boundary surfaces. For this purpose, using the theory of generalized functions, the coefficient of thermal conductivity of this structure is depicted as one unit for the whole system. In view of this, instead of two equations of thermal conductivity for the layer and the inclusion and conditions of perfect thermal contact on the surfaces of the junction between them, one equation of thermal conductivity was obtained in the generalized derivatives with breaking coefficients. We consider the case when the inclusion sizes are small compared to the distances from the inclusion surfaces to the boundary surfaces of the layer. In this connection, the combined thermophysical parameters were introduced and the thermal coefficients of the thermal conductivity equation were transformed into singular ones. For the solution of the boundary value problem of thermal conductivity containing this equation and boundary conditions on the boundary surfaces of the layer, an integral Fourier transform was used and, as a result, an analytical solution of the problem in the images was obtained. The inverse integral Fourier transform was applied to this solution, which made it possible to obtain the final analytical solution of the original problem. The analytical solution obtained is presented as a non-native double convergent integral. To determine the numerical values of the temperature in the above design, as well as to analyze the heat exchange between the layer and the environment caused by different temperature regimes due to the heating of the inhomogeneous layer by a heat source concentrated in the area of inclusion, computational programs have been developed. Using these programs, graphs are displayed showing the behavior of curves constructed using numerical values of the temperature distribution depending on the spatial coordinates for different inclusion materials. The obtained numerical values of temperature indicate a significant influence of the inclusion on its distribution in the design "layer-inclusion". The software also makes it possible to analyze these inhomogeneous media with respect to their heat resistance during heating. As a consequence, it becomes possible to raise and protect it from overheating, which can cause destruction not only of individual elements, but also of the whole structure.

Keywords: thermal 3D medium; temperature regimes; heat conduction; temperature field; foreign inclusion; ideal heat contact.

Introduction. Composite materials play an important role in the production of modern mobile devices, the creation of which is one of the leading problems in materials science. The emergence of new such materials with improved performance physical and mechanical properties will contribute to the creation of new technologies in aviation, space, shipbuilding, energy, electronics, mechanical engineering and transportation. Composite materials have an important role in film materials with foreign inclusions, which are widely used in the design of mobile devices.

Because during the operation of the devices their individual elements are subjected to different temperature influences, it is important to determine the temperature fields. This makes it possible to create mathematical models of heat transfer and to solve them on the basis of boundary value problems of mathematical physics, since experimental measurements are practically impossible here.
Analysis of literature sources and statement of the problem. Determination of temperature regimes both in homogeneous and in non-homogeneous structure attracts attention of many scientists (Carpinteri \& Paggi, 2008; Yangian \& Daihui, 2009).

In the paper (Ghannad \& Yaghoobi, 2015), an analytical-numerical solution of the axiallysymetric problem of thermoelastisity for a thick-walled cylinder under the action of heat flux with arbitrarily set boundary conditions. The obtained solution enables us to make analysis of the influence of thermal and mechanical loadings on thermo dynamic behavior of the cylinder.

A one-dimensional stationary temperature problem and a mechanical problem have been solved, and relationships for determination of thermal and mechanical loadings in a hollow thick-walled sphere are presented. The distribution of temperature is depicted by means of a function of radial coordinate for the given general thermal and mechanical

\section{Інформація про авторів:}

Гавриш Василь Іванович, д-р техн. наук, професор, кафедра програмного забезпечення. Email: gavryshvasyl@gmail.com; https://orcid.org/0000-0003-3092-2279

Король Олександр Сергійович, ст. викладач, кафедра фізичного виховання. Email: korol_lofkk@i.ua

Шкраб Роман Романович, асистент, кафедра програмного забезпечення. Email: shkrab@gmail.com

Квятковський Богдан Олександрович, канд. техн. наук, асистент, кафедра програмного забезпечення. Email: kviatkovskyi@gmail.com

Цитування за ДСтУ: Гавриш В. І., Король О. С., Шкраб Р. Р., Квятковський Б. О. Thermal 3D model for non-homogeneous elements in mobile devices. Науковий вісник НЛтУ України. 2019, т. 29, № 8. С. 130-133.

Citation APA: Havrysh, V. I., Korol, O. S., Shkrab, R. R., Kviatkovskyi, B. O. (2019). Thermal 3D model for non-homogeneous elements in mobile devices. Scientific Bulletin of UNFU, 29(8), 130-133. https://doi.org/10.36930/40290824 
boundary conditions at inner and outer surfaces of the sphere (Jabbari, Karampour \& Eslami, 2011).

In the paper (Bayat, Moosavi \& Bayat, 2015) a non-station of problem of heat conduction and thermoelasticity for functional-gradient thick-walled spheres is solved. Thermophysical and thermoelastical parameters of materials, except Poisson's ratio are arbitrary functions of radial coordinate.

Axially symmetric stationar problem of heat conduction and thermoelasticity for hollow functional gradient spheres with respect to the heat source is considered. Solution in the form of functions of spatial coordinates for temperature, for components of the vector of displacement, and for the tensor of stresses are obtained with the use of boundary conditions with respect to radial and angular coordinates (Mohazzab \& Jabbari, 2011).

Methods of solving linear boundary-value problems of heat conduction for homogeneous and layered 2D media with heat-active inclusions have been developed. Series of constructed mathematical models for determination of temperature fields in such media is presented. Ways of linearization of nonlinear boundary value problems of heat conduction in thermosensitive piece-wise homogeneous media are suggested; mathematical models of analysis of temperature regimes for linearly variable with respect to temperature coefficient of heat conductivity in the systems are presented (Gavrysh \& Fedasjuk, 2012).

A mathematical model for determination of temperature field which is caused by thermal heat flux in a thermosensitive $2 \mathrm{D}$ medium containing a through inclusion is given (Havrysh, 2017).

Our review of main literature sources has indicated that models which take into account piece-wise homogeneous structure and thermosensitivity remain poorly investigated and undeveloped. Since the structures are subjected to the temperature influences, in certain temperature ranges the influence of thermosensitivity on results of calculation of temperature fields becomes to be considerable. This leads to development of nonlinear models of the process of heat conduction and to their analysis, since the solutions of the problems which correspond to this models are more accurate than the solutions of corresponding linear boundary value problems. Calculation of temperature fields in such systems are further used for designing of complicated systems with the aim of thermostability. Precision of this calculation influences the effectiveness of the methods which are used in the course of designing.

Object of investigation and mathematical model. The 3D medium represented by isotropic layer which contains parallelepiped shaped inclusion whose volume $V_{0}=8 h b d=2 d S_{0}$ is considered. At one of the layer's surface $K_{b}=\left\{\left(x, y,-d-l_{b}\right):|x|<\infty,|y|<\infty\right\}$, there is a concentraited heat flow whose surface density is equal to $q_{0}=$ const , and the other surface $K_{n}=\left\{\left(x, y, d+l_{n}\right):|x|<\infty,|y|<\infty\right\}$, there are given the conditions of convective heat exchange with the external medium at the constant temperature of $t_{c}=$ const (fig. 1). The presented structure is referenced to the Cartesian coordinate system $(x, y, z)$ whose origin $O$ is located at the center of the inclusion. At the surfaces of the inclusion, there exist conditions of ideal heat contact (fig. 1).

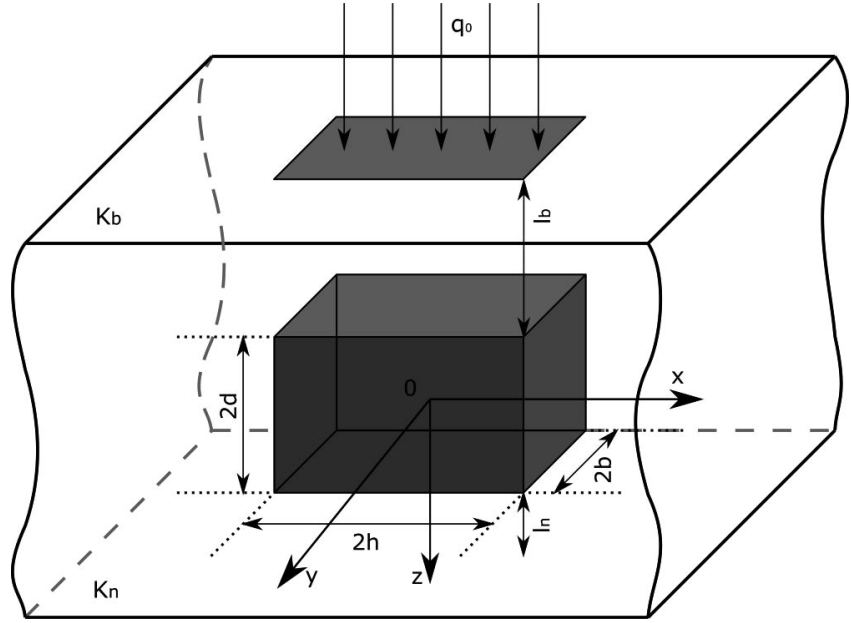

Fig. 1. Isotropic layer with inclusion

To determine the stationary temperature field $t(x, y, z)$ in the represented non-homogeneous medium, the equation of heat conduction is used

$$
\operatorname{div}[\lambda(x, y, z) \operatorname{grad} \theta(x, y, z)]=0 .
$$

Where $\lambda(x, y, z)=\lambda_{1}+\left(\lambda_{0}-\lambda_{1}\right) N(x, h) N(y, b) N(z, d)$;

$\theta(x, y, z)=t(x, y, z)-t_{c} ; \quad N(\zeta, \eta)=S(\zeta+\eta)-S(\zeta-\eta) ; \lambda_{1}, \lambda_{0}$ are the coefficients of thermal conductivity for the materials of the layer and of the inclusion, respectively; $S(\zeta)=\left\{\begin{array}{ll}1, & \zeta>0 \\ 0,5, & \zeta=0 \\ 0, & \zeta<0\end{array}\right.$ is the symmetric unit function.

The boundary conditions are of the form:

$$
\begin{gathered}
\left.\lambda_{1} \frac{\partial \theta(x, y, z)}{\partial z}\right|_{z=-d-l_{b}}=-Q(x, y), \\
\left.\lambda_{1} \frac{\partial \theta(x, y, z)}{\partial z}\right|_{z=d+l_{n}}=-\left.\alpha_{n} \theta(x, y, z)\right|_{z=d+l_{n}}, \\
\left.\theta(x, y, z)\right|_{|x| \rightarrow \infty}=\left.\theta(x, y, z)\right|_{|y|_{\rightarrow \infty}}=0,
\end{gathered}
$$

where $\alpha_{n}$ is the coefficient of heat removal from the boundary surface $K_{n}$ of the layer;

$$
Q(x, y)=q_{0} N(x, h) N(y, b) .
$$

Let us assumed that the size of the inclusion are small in comparison with the distances $l_{b}, l_{n}$ from its boundary surfaces $\Pi_{ \pm}=\{(x, y, \pm d):|x| \leq h,|y| \leq b\}$ to the boundary surfaces $K_{b}, K_{n}$ of the layes. Let us introduce the reduced heat conductivity $\Lambda_{0}=\lambda_{0} V_{0}$ of the inclusion, reduced surfaced density $Q_{0}=q_{0} S_{0}$ of the flow; and then let us take limit in the expressions (4) for $h \rightarrow 0, b \rightarrow 0, d \rightarrow 0 ; \quad \Lambda_{0}$ and $Q_{0}$ being constant and the known limit $\lim _{\eta \rightarrow 0} \frac{N(\zeta, \eta)}{2 \eta}=\delta(\zeta)$ being used. As result we obtain

$$
\begin{gathered}
\lambda(x, y, z)=\lambda_{1}+\Lambda_{0} \delta(x, y, z), \\
Q(x, y)=Q_{0} \delta(x, y) .
\end{gathered}
$$

Here $\delta(x, y, z)$ is the Dirac delta function.

Though the local non-homogenity of the layer is described by the relationship (4), which contain Dirac delta function, are formaly concentrated in the origin of the coordinate system, however, it is characterized by finite dimensions which are related with the volume $V_{0}$. Thus, with the help of the expression (5) the finite dimensions of the inclusion are effectively taken into account. 
Having substituted the expression (5) into the relationship (1), we obtain the equation

$$
\begin{gathered}
\Delta \theta+\frac{\Lambda_{0}}{\lambda_{1}}\left[\left.\frac{\partial \theta(x, 0,0)}{\partial x}\right|_{x=0} ^{*} \delta^{\prime}(x) \delta(y, z)+\right. \\
\left.+\left.\frac{\partial \theta(0, y, 0)}{\partial y}\right|_{y=0} ^{*} \delta^{\prime}(y) \delta(x, z)+\left.\frac{\partial \theta}{\partial z}\right|_{z=0} ^{*} \delta^{\prime}(z) \delta(x, y)\right]=0,
\end{gathered}
$$

where $\left.\frac{\partial \theta(x, 0,0)}{\partial x}\right|_{x=0} ^{*}=\frac{1}{2}\left[\left.\frac{\partial \theta(x, 0,0)}{\partial x}\right|_{x=+0}+\left.\frac{\partial \theta(x, 0,0)}{\partial x}\right|_{x=-0}\right]$;

$\Delta=\frac{\partial^{2}}{\partial x^{2}}+\frac{\partial^{2}}{\partial y^{2}}+\frac{\partial^{2}}{\partial z^{2}}$ is the Laplacian operator in Cartesian rectangular coordinate system.

Using the template. By means of the application of the integral Fourier transformation with respect to the coordinates $x$ and $y$ to the equation (7) under the conditions (3) and with taking into account the relationship (6), we obtain the following boundary value problem:

$$
\begin{gathered}
\frac{d^{2} \bar{\theta}(z)}{d z^{2}}-\gamma^{2} \bar{\theta}(z)=P_{2} \delta^{\prime}(z), \\
\left.\frac{d \bar{\theta}(z)}{d z}\right|_{z=-d-l_{b}}=P_{1},\left.\lambda_{1} \frac{d \bar{\theta}(z)}{d z}\right|_{z=d+l_{n}}=-\left.\alpha_{n} \bar{\theta}(z)\right|_{z=d+l_{n}},
\end{gathered}
$$

where $\bar{\theta}(z)=\frac{1}{2 \pi} \int_{-\infty}^{\infty} e^{i \alpha x} d x \int_{-\infty}^{\infty} \theta(x, y, z) e^{i \beta y} d y ; \gamma^{2}=\alpha^{2}+\beta^{2}$;

$$
P_{1}=-\frac{Q_{0}}{2 \pi \lambda_{1}} ; \quad P_{2}=-\left.\frac{\Lambda_{0}}{2 \pi \lambda_{1}} \frac{\partial \theta(0,0, z)}{\partial z}\right|_{z=0} ^{*} .
$$

Here, it is taking into account that

$$
\left.\frac{\partial \theta(x, 0,0)}{\partial x}\right|_{x=0} ^{*}=\left.\frac{\partial \theta(0, y, 0)}{\partial y}\right|_{y=0} ^{*}=0 .
$$

The equation (8) is solved by means of the method of variation of constant; and as result, it general solution is obtained in the form

$$
\bar{\theta}(z)=c_{1} e^{\gamma z}+c_{2} e^{-\gamma z}+P_{2} \operatorname{ch} \gamma z S(z) .
$$

The boundary conditions ( 9 ) have been used for determination of the constants $c_{1}, c_{2}$ of the integration and the partial solution of the problem (8), (9) has been obtained

$$
\begin{gathered}
\bar{\theta}(z)=P_{2}\left\{\operatorname{ch} \gamma z S(z)-\frac{1}{\Delta}\left[\gamma \operatorname{sh} \gamma\left(d+l_{n}\right)+\right.\right. \\
\left.\left.+\frac{\alpha_{n}}{\lambda_{1}} \operatorname{ch} \gamma\left(d+l_{n}\right)\right] \operatorname{ch} \gamma\left(z+d+l_{b}\right)\right\}- \\
-\frac{P_{1}}{\Delta}\left[\operatorname{ch} \gamma\left(z-d-l_{n}\right)-\frac{\alpha_{n}}{\lambda_{1} \gamma} \operatorname{sh} \gamma\left(z-d-l_{n}\right)\right] .
\end{gathered}
$$

The inverse integral Fourier transformation has been applied to the relationship (10). As result of this, the expression for the determination of temperature has been found

$$
\theta(x, y, z)=\frac{2}{\pi} \int_{0}^{\infty} \int_{0}^{\infty} \cos \alpha x \cos \beta \bar{y} \bar{\theta}(z) d \alpha d \beta
$$

According to the formulae (11), the following relationship for the determination of the value $\left.\frac{\partial \theta(0,0, z)}{\partial z}\right|_{z=0} ^{*}$ :

$$
\left.\frac{\partial \theta(0,0, z)}{\partial z}\right|_{z=0} ^{*}=
$$

$$
=\frac{-Q_{0} \int_{0}^{\infty} \int_{0}^{\infty} \frac{1}{\Delta}\left[\lambda_{1} \gamma \operatorname{sh} \gamma\left(d+l_{n}\right)+\alpha_{n} \operatorname{ch} \gamma\left(d+l_{n}\right)\right] d \alpha d \beta}{\pi^{2} \lambda_{1}^{2}-\lambda_{0} \int_{0}^{\infty} \int_{0}^{\infty} \frac{\gamma}{\Delta}\left[\lambda_{1} \gamma \operatorname{sh} \gamma\left(d+l_{n}\right)+\alpha_{n} \operatorname{ch} \gamma\left(d+l_{n}\right)\right] \operatorname{sh} \gamma\left(d+l_{b}\right) d \alpha d \beta},
$$

where $\Delta=\gamma \operatorname{sh} \gamma\left(2 d+l_{n}+l_{b}\right)+\frac{\alpha_{n}}{\lambda_{1}} \operatorname{ch} \gamma\left(2 d+l_{n}+l_{b}\right)$ has been obtained.

Thus, the unknown temperature field in a spatial medium with a heat-active inclusion is expressed by the formula (10). It enable us to develop algorithms and calculative programs for analysis of temperature regimes in elements or in individual assemblies of microelectronic devices, which can be geometrically describe by means of such structure.

Results of numerical calculations. For the case of thermoactive inclusion (in the region of inclusion evenly distributed internal heat sources), numerical calculations of the distribution of the loss temperature $\theta(x, y, z)$ depending on the spatial coordinate for $x=z=0$ are performed. The material of the layer was chosen ceramics VK94-1, and the inclusion material - silver (curve 1), aluminum (curve 2) and silicon (curve 3) (Fig. 2,a). As can be seen from the graphs, the inclusion material significantly affects the temperature distribution in the "layer-inclusion".
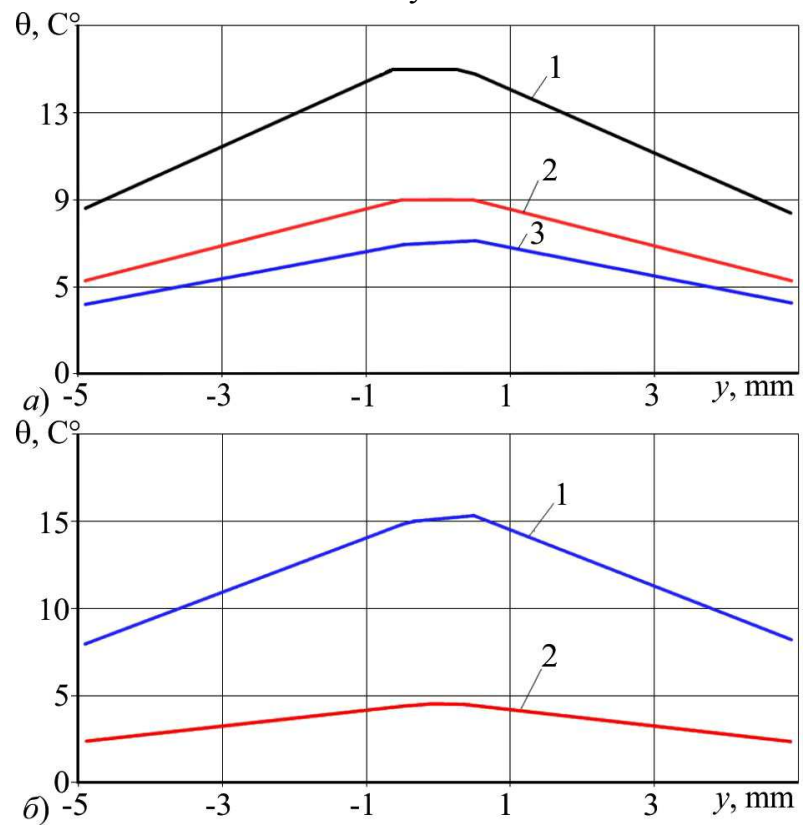

Fig. 2. Temperature $\theta(x, y, z)$ dependence on the spatial coordinate $y$

Fig. 2, $b$ illustrates the change in the loss temperature $\theta(x, y, z)$ from the spatial coordinate for $x=z=0$ in the construction "ceramics VK94-1 - silver" (curve1) and for the average value of the thermal conductivity coefficient of these materials (curve 2). The results of the calculations indicate that averaging the thermal conductivity coefficient for the structural materials of the system leads to a significant error.

Conclusions. Using the generalized functions and the Fourier integral for a spatial isotropic layer with inclusion and heat transfer, which is heated by heat flux, an analytical solution of the boundary value problem of thermal conductivity is constructed, the differential equation of which contains discontinuous and singular coefficients. This solution is given as a non-native double convergent integral. An algorithm and a calculation program for determining the tem- 
perature field at an arbitrary point of a layer with thermoactive inclusion have been developed. On this basis, the numerical values of the temperature field were obtained, using which graphs were displayed depicting curves illustrating the change of temperature depending on the spatial coordinate for the specified inclusion materials. As can be seen from Figure 2 the inclusion materials significantly affect the temperature distribution in the above design. This makes it possible to analyze heat exchange in inhomogeneous media with inclusions regarding their thermal stability during heating and to protect them from overheating, which can cause destruction not only of individual elements, but of the whole structure.

\section{References}

Bayat, A., Moosavi, H., \& Bayat, Y. (2015). Thermo-mechanical analysis of functionally graded thick spheres with linearly time-dependent temperature. Scientia Iranica, 22(5), 1801-1812.

Carpinteri, A., \& Paggi, M. (2008). Thermoelastic mismatch in nonhomogeneous beams. J. Eng. Math, 61, 2-4, 371-384.

Gavrysh, V. I., \& Fedasjuk, D. V. (2012). Modeljuvannja temperaturnyh rezhymiv u kuskovo-odnoridnyh strukturah. Lviv: Vyd-vo Nac. un-tu "L'vivs'ka politehnika", (pp. 176-178).

Ghannad, M., \& Yaghoobi, M. P. (2015). A thermoelasticity solution for thick cylinders subjected to thermo-mechanical loads under various boundary conditions. Int. Journal of Advanced Design \& Manufacturing Technology, 8(4), 1-12.

Havrysh, V. I. (2017). Investigation of temperature fields in a heatsensitive layer with through inclusion. Materials Science, 52(4), 514-521.

Jabbari, M., Karampour, S., \& Eslami, M. R. (2011). Radially symmetric steady state thermal and mechanical stresses of a poro FGM hollow sphere. International Scholarly Research Network ISRN Mechanical Engineering, 3, 1-7. https://doi.org/10.5402/2011/305402

Mohazzab, A. H., \& Jabbari, M. (2011). Two-Dimensional Stresses in a Hollow FG Sphere with Heat Source. Advanced Materials Research, 264-265, 700-705. https://doi.org/10.4028/scientific.net/amr.264-265.700

Yangian, Xu., \& Daihui, Tu. (2009). Analysis of steady thermal stress in a $\mathrm{ZrO} / \mathrm{FGM} / \mathrm{Ti}-6 \mathrm{Al}-4 \mathrm{~V}$ composite ECBF plate with temperature-dependent material properties by NFEM, WASE. Int. Conf. on Informa. Eng., 2-2, 433-436.

\section{В. І. Гавриш, О. С. Король, Р. Р. Шкраб, Б. О. Квятковський}

Національний університет "Львівська політехніка", м. Львів, Украӥна

\section{ТЕПЛОВА ЗD МОДЕЛЬ ДЛЯ НЕОДНОРІДНИХ ЕЛЕМЕНТІВ У МОБІЛЬНИХ ПРИСТРОЯХ}

Розроблено математичну модель аналізу теплообміну між навколишнім середовищем та ізотропним просторовим шаром із чужорідним включенням, який нагрівається тепловим потоком, зосередженим на одній із межових поверхонь. Для цього, з використанням теорії узагальнених функцій, коефіцієнт теплопровідності цієї конструкції зображено як єдине ціле для всієї системи. 3 огляду на це, замість двох рівнянь теплопровідності для шару і включення та умов ідеального теплового контакту на поверхнях стикування між ними отримано одне рівняння теплопровідності в узагальнених похідних із розривними коефіцієнтами. Розглянуто випадок, коли розміри включення $\epsilon$ малими порівняно з відстанями від поверхонь включення до межових поверхонь шару. Тому введено зведені теплофізичні параметри і розривні коефіцієнти рівняння теплопровідності переходять у сингулярні. Для розв'язування крайової задачі теплопровідності, що містить це рівняння та крайові умови на межових поверхнях шару, використано інтегральне перетворення Фур'є і внаслідок отримано аналітичний розв'язок задачі в зображеннях. До цього розв'язку застосовано обернене інтегральне перетворення Фур'є, яке дало змогу отримати остаточний аналітичний розв'язок вихідної задачі. Отриманий аналітичний розв'язок подано у вигляді невласного подвійного збіжного інтегралу. Для визначення числових значень температури в наведеній конструкції, а також аналізу теплообміну між шаром та навколишнім середовищем, зумовленим різними температурними режимами завдяки нагріванню неоднорідного шару джерелом тепла, зосередженим в області включення, розроблено обчислювальні програми. Із використанням цих програм наведено графіки, що відображають поведінку кривих, побудованих із використанням числових значень розподілу температури залежно від просторових координат для різних матеріалів включення. Отримані числові значення температури свідчать про значний вплив включення на її розподіл в конструкції "шар-включення". Програмні засоби також дають змогу аналізувати такого роду неоднорідні середовища щодо їх термостійкості під час нагрівання. Як наслідок, можливо іï підвищити і захистити від перегрівання, яке може спричинити руйнування не тільки окремих елементів, а й всієї конструкції.

Ключові слова: теплова 3D модель; температурні режими; теплопровідність; температурне поле; чужорідне включення; ідеальний тепловий контакт. 